\title{
Business Model as an Effective Concept for the Development of Strategic Thinking Skills of Managers in Universities and Enterprises Partnerships
}

\author{
Natalia D. Strekalova \\ Herzen State Pedagogical University of Russia \\ St. Petersburg, Russia \\ strekalova_spb@mail.ru
}

\author{
Elena V. Korchagina \\ Peter the Great St. Petersburg Polytechnic University \\ St. Petersburg, Russia \\ State Institute of Economics, Finance, Law and Technology \\ (SIEFLT) \\ Gatchina, Russia \\ elena.korchagina@mail.ru
}

\author{
Daria A. Korchagina \\ Honeywell JCS; \\ Peter the Great St. Petersburg Polytechnic University \\ St. Petersburg, Russia \\ elena2112201@mail.ru
}

\begin{abstract}
The article is devoted to the problem of applying a business model for developing strategic thinking skills in a partnership between universities and industrial enterprises. The strategic thinking is a key competence of enterprise managers in modern conditions. However, there is still no complete clarity on how to develop it. The tasks of developing strategic thinking of managers can be successfully solved through design and application of business models. The use of strategic partnerships between universities and enterprises in this process allows us to improve the quality of training and ensure its relevance to the Russian business practice. The article proposes an integrated approach for the strategic thinking skills development based on the use of business models. The process model was developed and tested in the training groups of the masters of management and practicing managers. Positive dynamics was revealed in the development of strategic thinking skills, as well as an increase in the level of student satisfaction. The results of this work can be interested for business education, and may also be useful in management practice for strategic sessions holding.
\end{abstract}

Keywords-business model; strategic thinking; business education; case studies; universities and enterprises strategic partnership

\section{INTRODUCTION}

The strategic thinking of managers is a key factor of effective management in various industries, and its value is growing steadily. At the same time, only a small part (23\%) of managers has strong practical skills of strategic thinking. The underdevelopment of strategic thinking is called among the main factors leading to the bankruptcy of companies and decrease of the business efficiency [1]. The results of a survey of Russian employers showed that the strategic thinking of managers is among the most relevant and demanded competencies (an average score of 4.5 out of 5) [2, 3] However, there is still no complete clarity on how to develop these skills.

The use of business models of existing enterprises in the educational process allows us to successfully solve the problems of formation and development of managers' strategic thinking skills. The strategic partnership of universities and industrial enterprises in this process contributes to an increase in the quality of training, its relevance to Russian business practice, and the solution of enterprise problems [4]. Case studies help to find approaches for solving managerial problems and developing research and training activities. These cases should be based on the problematization of managers' work experience and researchers' academic interests. Thus they can be used both in business practice and in the educational process.

\section{StATEMENT OF THE ReSEARCh PRoblem}

Modern business education does not pay due attention to the practical skills formation of the strategic thinking. This is partly due to the complexity of research on the strategic process itself as well as the cognitive and socio-behavioral aspects of managerial activity. Business transformations in the time of the external environment volatility lead to radical changes in the business models of enterprises. The business models of successful enterprises are of great interest to business scientists and practitioners. However, these business models are poorly represented in the practice of strategy training for managers.

The purpose of the article is to develop a process model for training managers in strategic thinking skills based on the use of a business model as a conceptual and analytical tool and to 
test it on the basis of a case study of the real existing company. We have used the case of Russian company called the Pobeda LSR JSC (part of the LSR Group) as an empirical basis for the study. This company is successfully operating in the construction materials market in the northwestern region of Russia.

\section{RESEARCH METHODOLOGY}

We have used the following methodological basis of the study: the concept of a business model; strategic, process, competence and situational approaches; a case study design. Our case study covers the ten-year period (1997-2007) of the LSR Group's leadership strategy implementation (Pobeda LSR JSC) in the Russian construction materials market $[5,6]$. The data collection and analysis for the case study was carried out on the basis of the methods of structured interviews by top managers, employee surveys, observation, analysis of primary documents and other company materials. A longitudinal study was conducted in 2006-2008 and 2013-2014.

The phenomenon of strategic thinking was initially considered in the literature mainly from the point of psychology as a special cognitive ability. However over the past ten years, an increasing number of researchers have interpreted it as a unique set of competencies of strategic managers. We consider strategic thinking as a special, complex type of intellectual managerial activity, the implementation of which depends on a set of competencies. The implementation of the competency-based approach involves the use of strategic thinking competencies: a set of skills and abilities that affect the development of strategies, business models and strategic actions that lead to effective business [7].

It is known that best results of trainings for the Russian students and practice managers required the case analysis developed on the basis of successful companies and the Russian business practices. Therefore, the situational approach (case study) was the basis for the development of strategic thinking skills. The process approach for the strategic thinking development has included the implementation of a certain sequence of individual and collective cognitive actions that unfold in time and in a specific context. The learning process should be based on an integrated approach based on competency, situational and process approaches.

The starting point in the learning process is to determine the essence of the business model. In modern literature, there are three main positions of scientists that reflected the economic, operational and strategic levels of its understanding. The first of them focuses on the financial and economic aspects of activity. The second one focuses on internal business processes and operations. We adhere to the third (strategic) position, which focuses on the strategic aspects of the company's business. It is based on the following understanding: "A business model is a brief description of how a set of interconnected elements that reflect decisions in the field of strategy, structure and economic activity of an enterprise will be used to create a sustainable competitive advantage in certain markets" [8].
Different authors in the structure of the business model propose to consider a different number of components: from four to eight. As a basis, we have taken the structure (integrative framework) [8]. It includes six components that reflect a set of decisions at three specific levels: the "foundation", the "proprietary", and the "rules" level. The first component reflects the factors associated with the supply of value to the consumer and answers the question "How will the company create value?" The second component describes market factors. Its main question is "For whom will the company create value?" The third component characterizes the factors of the internal capabilities of the company and answers the question "What is the source of the company's advantage?" The fourth component reflects factors related to competitive strategy "How does the company position itself in the market?" The fifth component characterizes economic factors "How will the company make money?" The sixth component reflects factors related to the goals and ambitions of business owners.

If the first ("basic") level focuses on what the company is doing, the second ("own") level shows how company does it. The first level is sufficient to reflect the essence of the business model of any company. The second characterizes the features of the business model of this particular company. At the third level ("rules"), a set of guidelines and rules governing the implementation of decisions at the first two levels of the model can be indicated.

\section{RESEARCH RESULTS AND DISCUSSION}

The process model of training in general can be represented as a structured process that includes five main stages that reflect key issues and actions for understanding and discussing the business model.

Stage 1. Analysis of the external environment.

Question: What are the threats / opportunities?

Action: conduct a SWOT analysis.

Assessment: threats / opportunities.

Stage 2. General characteristics of the business model.

Question: What is the existing business model?

Action: analyze the structure and main components of the business model.

Assessment: qualitative / quantitative assessment of the main components of the business model.

Stage 3. Identification of competitive advantages.

Question: What are company competitive advantages and what are its sources?

Action: identify sources of competitive advantage.

Assessment: competitive advantage.

Stage 4. Checking the business model for compliance and sustainability.

Question: What is a relation between the elements and the sustainability of the business model? 
Action: analysis of the relation between the elements of the model and the competitive strategy, stability analysis.

Assessment: compliance / non-compliance, sustainability.

Stage 5. Generation of ideas.

Question: How can company use opportunities / decrease the threats level to create value; create / maintain / enhance competitive advantage?

Action: developing ideas for creating value, building up a competitive advantage.

Assessment: necessary resources, degree of readiness for changes.

TABLE I. DESCRIPTION OF THE BUSINESS MODEL OF JSC "POBEDA LSR"

\begin{tabular}{|c|c|c|}
\hline $\begin{array}{l}\text { Components } \\
\text { Native }\end{array}$ & Basic Level & Own Level \\
\hline $\begin{array}{l}\text { Component } 1 . \\
\text { Value factors }\end{array}$ & $\begin{array}{l}\text { Product manufacturing } \\
\text { (Ceramic Brick); } \\
\text { Standard offer; } \\
\text { Wide range of } \\
\text { assortment; } \\
\text { Deep assortment } \\
\text { coverage; } \\
\text { Direct sales; } \\
\text { Sales through } \\
\text { intermediaries }\end{array}$ & $\begin{array}{l}\text { Product with delivery (on } \\
\text { orders, just in time); } \\
\text { High quality product; } \\
\text { Over } 40 \text { types of bricks } \\
\text { and ceramic products; } \\
\text { Direct Sales (B2B): } \\
\text { construction companies; } \\
\text { Sales through } \\
\text { intermediaries (B2C): } \\
\text { construction bases, } \\
\text { hypermarkets, dealer } \\
\text { clubs, the brick center } \\
\text { retail chain }\end{array}$ \\
\hline $\begin{array}{l}\text { Component } 2 . \\
\text { Market } \\
\text { factors }\end{array}$ & $\begin{array}{l}\text { B2B and B2C market } \\
\text { (corporate and individual } \\
\text { clients); } \\
\text { Regional market (St. } \\
\text { Petersburg and Leningrad } \\
\text { region); } \\
\text { Wide market coverage: } \\
\text {-construction companies, } \\
\text {-individual developers; } \\
\text { Relationship building } \\
\text { (B2B) }\end{array}$ & $\begin{array}{l}\text { Managed development } \\
\text { (growth): } \\
\text { retention of regional } \\
\text { market share and seizing } \\
\text { opportunities for growth } \\
\text { (regional expansion) } \\
\text { B2B ( } 80 \% \text { of the market), } \\
\text { B2C (20\% of the market); } \\
\text { Close trusting } \\
\text { relationships on a long- } \\
\text { term, mutually beneficial } \\
\text { basis (for corporate } \\
\text { clients) }\end{array}$ \\
\hline \multirow[t]{2}{*}{$\begin{array}{l}\text { Component } 3 . \\
\text { Internal } \\
\text { capabilities }\end{array}$} & $\begin{array}{l}\text { Own production / } \\
\text { Operating systems; } \\
\text { Mass production; } \\
\text { Modern equipment; } \\
\text { Advanced technology }\end{array}$ & $\begin{array}{l}\text { Production specialization } \\
\text { (in factories); } \\
\text { Total capacity - } 290 \\
\text { million bricks per year; } \\
\text { Innovation in operating } \\
\text { systems; } \\
\text { High efficiency of } \\
\text { factories capacity } \\
\text { utilization; } \\
\text { Production planning } \\
\text { optimization; } \\
\text { Effective marketing and } \\
\text { sales system; } \\
\text { Accepting orders on the } \\
\text { internet }\end{array}$ \\
\hline & $\begin{array}{l}\text { Raw material base; } \\
\text { Intangible assets; } \\
\text { Investment resources }\end{array}$ & $\begin{array}{l}\text { Own clay pits; } \\
\text { Brick brand, trademarks } \\
\text { ("Ceramics", "Rauf"); } \\
\text { Access to corporate } \\
\text { investment sources; } \\
\text { Administrative resource }\end{array}$ \\
\hline
\end{tabular}

\begin{tabular}{|c|c|c|}
\hline & $\begin{array}{l}\text { Developed network of } \\
\text { cooperation and } \\
\text { partnership; } \\
\text { Key role in business } \\
\text { network }\end{array}$ & $\begin{array}{l}\text { Joint implementation of } \\
\text { orders for complex } \\
\text { projects; } \\
\text { Complete set with various } \\
\text { types of building materials }\end{array}$ \\
\hline & $\begin{array}{l}\text { Strong corporate culture; } \\
\text { Personnel motivation } \\
\text { systems }\end{array}$ & $\begin{array}{l}\text { Promoting innovations } \\
\text { and entrepreneurship (at } \\
\text { all levels); } \\
\text { Provision of employees: } \\
\text { - professional career } \\
\text { growth, } \\
\text { - social protection } \\
\text { programs, } \\
\text { - salary is above industry } \\
\text { average }\end{array}$ \\
\hline & $\begin{array}{l}\text { High professionalism of } \\
\text { management; } \\
\text { Qualified engineering } \\
\text { staff }\end{array}$ & $\begin{array}{l}\text { Sharing knowledge, } \\
\text { information and best } \\
\text { practices; } \\
\text { Policies for the hiring and } \\
\text { retention of valuable } \\
\text { employees }\end{array}$ \\
\hline $\begin{array}{l}\text { Component } 4 . \\
\text { Competitive } \\
\text { strategy } \\
\text { factors }\end{array}$ & $\begin{array}{l}\text { High quality product; } \\
\text { Wide range of products; } \\
\text { Image of the "company } \\
\text { with which it is } \\
\text { convenient to work"; } \\
\text { Stability / reliability }\end{array}$ & $\begin{array}{l}\text { Differentiation is achieved } \\
\text { through: } \\
\text { - high quality product; } \\
\text { - variety of assortment; } \\
\text { - stability, reliability, } \\
\text { uninterrupted supply; } \\
\text { - offer a comprehensive } \\
\text { solution to customer } \\
\text { problems (a wide range of } \\
\text { building materials) }\end{array}$ \\
\hline $\begin{array}{l}\text { Component } 5 . \\
\text { Economic } \\
\text { factors }\end{array}$ & $\begin{array}{l}\text { Permanent income } \\
\text { source; } \\
\text { Large production } \\
\text { volumes; } \\
\text { Flexible prices; } \\
\text { High share of fixed costs } \\
\text { in the total cost structure; } \\
\text { Average cost; } \\
\text { Average rate of return }\end{array}$ & $\begin{array}{l}\text { Product sales ( } 95 \% \text { of } \\
\text { revenue); } \\
\text { Delivery and related } \\
\text { products ( } 5 \% \text { of revenue); } \\
\text { Price level (between high } \\
\text { and medium); } \\
\text { Economies of scale; } \\
\text { Profitability growth }\end{array}$ \\
\hline $\begin{array}{l}\text { Component 6. } \\
\text { Growth } \\
\text { factors }\end{array}$ & Growth Model & $\begin{array}{l}\text { Focus on business- } \\
\text { compatible growth } \\
\text { opportunities }\end{array}$ \\
\hline
\end{tabular}

Table I illustrates the application of the previously described structure (integrative framework) to the study of the characteristics of the business model of "Pobeda LSR". The "Pobeda LSR" has a logical and effective business model that allows it to maintain high business growth for many years. The company became the leader in the regional market with $69 \%$ market share ten years after its entering the construction materials market of the North-West region of Russia. "Pobeda LSR" was able to overcome the difficulties of the economic and financial crises in 1998 and 2008, and the construction industry crisis in 2004, which for other companies were the serious tests of survival.

There are several factors at the heart of the "Pobeda LSR" business model: the leader strategy, emphasis on the use of growth opportunities, including mergers and acquisitions; focus on value proposition, mass market and innovation. The first (basic) level in the table gives a general description of what the company does with its resources and capabilities. This level reflects the company choice of possible alternatives for answering a standard set of questions in relation with the six components of the model. So, the table shows that on the basic level the company offers a product (ceramic brick) and 
services (product delivery) with a prevailing focus on the product ( $95 \%$ of revenue), using primarily direct sales, as well as sales through intermediaries. The company has a wide coverage of the $\mathrm{B} 2 \mathrm{~B}$ and $\mathrm{B} 2 \mathrm{C}$ market, own mass production, access to sources of raw materials, a developed network of cooperation and partnership, etc.

The second (own) level of the model reflects the specific features of the business model related to innovation, key competencies and internal capabilities. It characterizes the company's ability to create and use unique combinations of several business model components, which ensures the company's competitive advantages.

For example, innovations in value proposition ensured the production of high-quality products and on-time delivery, a wide range of assortments (over 40 types of bricks and ceramic products of various profiles, sizes, grades and colors). The unique characteristics of the operating system, due to the introduction of a number of process innovations, have led to stability, reliability and uninterrupted supply, as well as to significant increase in product quality, optimization of operational-production planning, acceptance of orders on the Internet, etc. Marketing innovations related to market segmentation have allowed company to develop differentiated service functionality and unique offers for each target segment. Brick brand development, the introduction of two brands ("Ceramics", "Rauf"), organizational and process innovations in the field of marketing and sales contributed to a flexible pricing policy, improving the quality of customer service. As a result, the company have used the economies of scale, increased product profitability, and increased sales.

The experimental verification of the operability and effectiveness of the proposed process model was carried out using the experimental method in the both master students in management and practicing managers training groups. The results showed that the use of the business model learning approach can significantly clarify the manager's strategic thinking and facilitates the process of building managerial skills. The experiment in the training groups showed positive results in comparison with the control group in the development of strategic thinking skills and the level of student satisfaction.

\section{CONCLUSION}

The study showed the effectiveness of the business model as a conceptual and analytical tool for developing managers' strategic thinking skills. We have shown the implementation of the integrated model to educational process on the basis of the competent, situational and process approaches. We have developed and tested the process model that includes five main stages, which allows developing managers' strategic thinking skills on the real company business model basis.

The results of the study are interesting for both universities and enterprises in the conditions of strategic partnership between them because this educational approach can improve the training quality and its relevance to business practice. Moreover it can be useful for solving the enterprises problems, and developing strategic thinking of managers. The results of this work can be used both in modern business education and in holding strategic sessions for managers.

\section{REFERENCES}

[1] Hortwath R. 2014. Elevate: The Three Disciplines of Advanced Strategic Thinking. New Jersey, Wiley.

[2] Russia 2025: From Personnel to Talent. 2017. The Boston Consulting Group.

[3] Desfonteines L., Korchagina E., Varnaev A., Semenova J. 2019. Organizational culture of trade enterprises in the context of modern demographic challenges and the use of information technology. Proceeding of the 2d International Scientific Conference on Digital Transformation on Manufacturing, Infrastructure and Service (DTMIS2018). IOP Conf. Ser.: Mater. Sci. Eng. Vol. 497. Is.1. 012117. https://doi.org/10.1088/1757-899X/497/1/012117

[4] Korchagina E.V., Shvetsova O.A. 2018. Solving the Problem of Employment for Graduates of Higher Education Institutions: Increasing the Degree of Employers' Participation in the Educational Process. Proceedings of 2018 17th Russian Scientific and Practical Conference on Planning and Teaching Engineering Staff for the Industrial and Economic Complex of the Region, PTES 2018. P. 138-140.

[5] Strekalova N.D. 2014. Kejs-metod v obuchenii strategicheskomu menedzhmentu [Case study in strategic management training]. St. Petersburg: Asterion Publ., 2014. (In Russian)

[6] Strekalova N., Kaysarov A. 2014. Leadership Strategy of LSR Group on the Russian Ceramic Brick Market. International Journal of Case Method Research \& Application. No. 2. P. 136-144.

[7] Strekalova N.D. 2018. Strategic thinking of managers: essence, problems and approaches to development. Vestnik Sankt-Peterburgskogo universiteta. Menedzhment [Bulletin of St. Petersburg University. Management]. 2018. Vol. 17. Vol. 3. S. 384-411 https://doi.org/10.21638/11701/spbu08.2018.306 (In Russian)

[8] Morris M., Schindehutte M., Allen J. 2005. The entrepreneur's business model: toward a unified perspective. Journal of Business Research. 58, p. 726-735. 